\title{
Infusion Of Techno Pedagogy In Elementary Teacher Education Curriculum: Perspectives And Challenges
}

\author{
Leema K M, Dr. T. Mohamed Saleem \\ (Research Scholar, Farook Training College, Affiliated to Calicut University, India) \\ (Assistant Professor, Farook Training College, Affiliated to Calicut University, India)
}

\begin{abstract}
Acquiring techno-pedagogical proficiencies will make teaching and learning a pleasurable exercise as it would minimize the pressure on the teachers and enable the students to delve deeper into domain of knowledge. Teacher education curriculum is responsible for imparting such abilities to modern teachers. This paper is an effort to review newly revised and restructured elementary teacher education curriculum of Kerala for contents to improve techno pedagogical skills of student teachers. And the paper will try to perform analysis on the effectiveness of the current contents enabling techno pedagogical skills, in the teacher education curriculum of Kerala and also, it will try to identify the challenges in transaction of technological contents in current syllabus. Despite the existing contents for enabling techno pedagogical skills, there are still many areas need improvement, the paper will also provide suggestions for further development in those sections.
\end{abstract}

$\underline{\text { Keywords - infusion, techno pedagogy, elementary teacher education curriculum }}$

\section{INTRODUCTION}

During last few decades the educational scenario is undergoing a paradigm shift in teaching techniques with the introduction of information and communication technologies. Teaching, hard to imagine theories with the help of simulations and other such ICT enabled methods is becoming very common. For inculcating such things in the classroom activities, teachers have to become techno-pedagogue. Imagine teachers teaching theories, by giving up the mechanical approach and making it interesting by simulating problems and finding solutions to such imaginary issues. Teachers with appropriate techno-pedagogical skills can make teaching a pleasurable experience without feeling much of pressure. Transformation from teachers to techno-pedagogue would not only increase the capability of the teachers but would also widen the knowledge base of students so as make them competitive in the international arena. It will be interesting to know; how present teacher education curriculum will motivate and facilitate pre-service teachers to evolve as a techno-pedagogue. This paper will review elementary teacher education curriculum in Kerala with that motive.

Beaudin and Hadden (2004) revealed in their study that techno-pedagogical skill helps the students for further development, accomplishment of learning outcomes and preserve the context of designing classroom based resources through the use of ICT by the teachers. Therefore, techno-pedagogy method was an essential component of teacher education. Koehler and Mishra (2005) found in their study that better teaching was not simply adding technology rather the introduction of technology causes the representation of new concepts and needs developing sensitivity to the dynamic, transactional relationship among technology, pedagogy, content and knowledge. The National Curriculum Framework (2005), identified that "ICT if used for connecting children and teacher with scientist working in universities and research institutions would also help in demystifying scientist and their work". However, research findings have shown that there exist socio-economic, cultural, time and geographical blockades for people who wish to pursue higher education. Innovative use of Information and Communication Technology can possibly solve this problem (Bhattacharya and Sharma, 2007). Techno-pedagogical knowledge carried out based on to increase the effectiveness of learning and teaching process for professional development by technology integration (Archambault \& Crippen, 2009; Cox \& Graham, 2009). The National Curriculum Framework (2009) stated that "ICT can be imaginatively drawn upon for professional development and academic support of the pre-service and in-service teachers." Lee and Tsai (2010) found that meaningful use of ICT in the classroom demands the teachers to integrate technological affordances with pedagogical approaches for the specific subject matter to be taught. Yurdakul (2011) exposed in his study that pre-service teachers need to provide opportunities to get practical knowledge and skills to use current technology during their training process. For that courses techno-pedagogical knowledge need to be added in teacher training programs. The technology centers in teaching and learning must be started in higher education institution.

Report of the working group on higher education for the XII five-year plan (2011), entitled that "Information and Communication Technology is a mission mode project to provide connectivity, valuable 
content and low cost computing devices to all the Institutions of higher learning in the country. A National Knowledge Network will interconnect all universities, libraries, laboratories, hospitals and agricultural institutions for sharing data and computing resources across the country over a high-speed information network having gigabit capabilities. Every teacher should understand how to use technology, pedagogy and subject area content effectively in their daily classroom teaching. It is clear that merely introducing technology to the educational process is not sufficient. One must ensure technological integration since technology by itself will not lead to change. Rather, it is the way in which teachers integrate technology that has the potential to bring change in the education process. For teachers to become fluent in the usage of educational technology means going beyond mere competence with the latest tools to developing an understanding of the complex web of relationships among users, technologies, practices, and tools. Teachers must understand their role in technologically-oriented classrooms. Sathiyaraj and Rajasekar (2013) found in their study that the technopedagogical expertise needs to be improved in order to equip teachers to face the students belong to the digital era and also to face the challenges in the modern classroom. Monsiváis, McAnally and Lavigne (2014) disclosed in their study that the integration of ICTs in the classroom depends on the teachers' ability to scaffold the learning environment by using effective ICT-based pedagogies.

\section{OBJECTIVES}

$>$ To review the newly revised elementary teacher education curriculum of Kerala

$>$ To give suggestions for effective integration of techno pedagogical skills in elementary teacher education curriculum

$>$ content analysis

\section{METHODOLOGY}

\section{REVIEW OF THE ROLE OF TECHNOLOGY IN ELEMENTARY TEACHER EDUCATION SYLLABUS}

The elementary teacher education curriculum is organized into three broad areas such as psychological and philosophical foundations of education, curriculum and pedagogy and school internship. Curriculum and pedagogy comprised of languages, art education, health and physical education, and optional subjects like mathematics, general science and social science. All these areas are further sub divided into twenty-two papers across four semesters. The techno pedagogical contents are distributed across these four semesters. A detailed analysis of semester wise presence of technological content is provided below.

\subsection{First semester}

In child development and learning paper have following transaction methods, using ICT. First one is about making presentation on how to select concept areas of various subjects can be prepared for students of various developmental stages. Second is, with the help of one or two simple cartoon films, analyses how cartoon films influence character formation, behavior and learning of children, based on the responses gathered. In Curriculum and pedagogy paper, running thread section suggests that ICT must be used for data collection mentioned in the syllabus so it mandates to teach, the basic lessons of I.C.T and their scope in teaching, through different units in this section. Also, one of the teacher competency item is identified as skills in ICT, Video analysis of classes taken by self and peers added as one of the transaction method. Teaching materials section gives introduction of use of computers, laptop and LCD projectors and also, it talks about the application of ICT Fifth Paper in first semester is completely dedicated for the introduction of ICT in the teaching/learning process. This unit discusses following things, Historical background of ICT and Education such as, The origin of ICT, The entry of computers, Software and Open Software and Use of ICT in learning activities. ICT and the society section deals about the possibilities in various fields (Health, Vocation, Industrial), Learning approach for familiarising ICT, Using finding, Visual equipment, With the help of computers, Qu live possibilities and Elearning. ICT in teaching process section talks about preparing and presenting PowerPoint presentations, Utilize Video clips, Use of Internet and Use of social networking. The role of ICT in making the teachers' vocation excellent is a section debates on data collection utilising Internet and other modes of technology, Internet, Websites, Blogs, Wikipedia and Online libraries. Information Processing section is about preparation of mark list, grading, collecting data on students, preparation of ETM, preparation of ETB and Digital portfolio. Transactional methods section dedicated to (For making the students hard over information on the school to the society and other related institution), Internet, Blogs, School Blogs, Social networks and Websites. Cyber Crime unit discuss about cybercrimes, such as Email harassment, Hacking and cracking, Misuse of internet etc. This paper also gives information on Hardware, Software, Utilizing video camera LCD and Digital Camera for the purpose of learning, Application Software. The information and skills gathered though ICT is applied through concept formation and communication. Presentation, Video clippings, Images, Text files, Audio files, Internet, blogs and websites 
This paper identifies the following transaction points such as, understanding that the effective use of ICT is essential in the teaching /learning process. Analyze various learning approaches which use ICT. Understands the possibilities of ICT in the teaching process. Conduct online discussions using social networking service. Identifies the use of ICT in data collection, identify the facilities when ICT is made use of in data collection. Construct a page in Wikipedia related to science. Understands that the skill for processing information increases teaching skill. Store the information collected using ICT in digital portfolio. Identifies that knowledge of ICT is the best way to share information on school with others. Use of blogs to share news in school. Understand expertise in ICT helps in excellence in vocation and utilising ICT for the improvement of teaching/learning process. Gathers data from internet on a science lesson and uses in teaching. Identifies that even abstract ideas can be effectively transacted with the help of audio visual indicators and though ICT. How can ICT be utilized in idea formation and transaction in the teaching/learning process. Prepare an Electronic Teaching Manual by making a Lesson Plan on a Science Lesson, using ICT. You tube videos and web links are added in language learning papers in first semester.

\subsection{Second semester}

In the paper for English language teaching, ICT was used in the following areas like, strategies for making learning more authentic using ICT and web resources. Transaction section of English language learning paper provide various web recourses that can be utilized for the same and also asks to prepare a presentation on 25 most useful websites that can be used for elementary level learners. YouTube links are provided for classroom transaction and strategies, multiple intelligence, language acquisition, concepts of mentoring and collaborative learning strategies. The Environmental studies paper have a transaction for Understanding new trends and contemporary developments through ICT \& reference and about use of ICT in Daily planning of teaching manual processes. In teaching Mathematics paper, observations using ICT is added. In Art education paper, ICT is suggested to use for construction of teaching tools, gathering folk paintings and Rangolies, organising vocal workshops and expert classes, and for constructing experiences. Visual Aids and ICT tools are included in all possible sections for the transaction of work education and health and physical education units.

\subsection{Third semester}

Even though ICT is identified as a transaction method in the introduction of the paper 'Learner and acquisition of Knowledge', no specific transaction item or syllabus content is present. In Social, Historical and Philosophical foundations of Education paper specifies a transaction item for Prepare tools (Panel, PowerPoint, Documentary) required for generating awareness by collecting photographs, video clips and reports on ICT enabled classroom facility. In art education and work experience paper following transaction like, assess presentation of drama using ICT and Analysis of text - planning of lesson- production of teaching learning materials finding possibilities of ICT, are present. In Work education, a unit is dedicated for possibilities of ICT which comprises of Preparation of video documentary and editing, Computer assembling and repair, and Preparation of software for presentation. Visual aids and ICT is mentioned for most of the teaching activities for health and physical education paper in this semester. In the optional mathematics/Social science/General science paper following transaction items make use of ICT such as Promotes, appreciation of geometrical aesthetics using ICT possibilities, using ICT possibilities explore and appreciate beauty and mobility of geometry, Finding Biographies of scientists by using ICT and Exhibition of video clippings of good Science classes.

\subsection{Fourth semester}

Language proficiency paper in this semester uses technology in following locations: record video and evaluates one minute speeches of student teachers, understand use of language in media such us Visual media (Short films, documentaries etc.) and social media (Blog, twitter etc.). Practical training in Mother tongue computing, computerizing documents, Formulating activities, using equipment's for children requiring special consideration and using different software and familiarizing various software for educational purpose are also present in language papers. In teaching English paper, a section of unit two is dedicated for the use of ICT with topics like: Basic computer literacy, preparing presentations, accessing websites such as wikis, creating blogs, accessing YouTube, Teacher Tube, podcasts, downloading, uploading, editing resources and Hypertext. YouTube or Web resources were provided for changing roles of teacher as mentors, learning passive voice etc. Evaluating Websites for Authenticity, Accuracy, themes, intended audience, feature etc. is another topic. Optional subject papers (Teaching Mathematics/Teaching Social Science/Teaching General Science) in fourth semester, make uses ICT in following items like, usage of ICT possibilities to enhance appreciation of geometrical patterns and identify the dynamic nature of geometry. Using the tools like, Dr. Geo and Geogebra. Made use of ICT possibilities be to identify dynamic nature of geometry. Conducts ICT presentation to explain the concept that history is the study about continuity and change. Use of Geographic gird, GPS, GIS, Maps. Social science teaching techniques using E-learning, blogging, Multimedia approach, ICT integrated learning. 
Prepare presentation on the stages of growth in the fields of biotechnology, information and communication technology by conducting ICT reference.

From the review of newly revised syllabus we can find that there occupy enormous potentialities for the use of technology in the new syllabus.

\section{CHALLENGES FOR IMPLEMENTATION OF TECHNO PEDAGOGY IN ELEMENTARY TEACHER EDUCATION SYLLABUS}

According to NCFTE 2009 elementary teacher education is the most critical but mostly ignored field of teacher education by the authorities. Elementary teacher education needs critical review for many of the aspects, ICT is the most important one. The entry qualification for the elementary teacher education is upgraded to higher secondary level. The technology content provided in the syllabus can be learned by the student with higher secondary level of knowledge. But the ability teacher educators transacting this curriculum is a concern. Even though qualification of student teachers were increased but teacher educators are still having qualifications for teaching secondary level. Most of the teachers have more than fifteen years of experience and doesn't studied ICT at any level of their college education. So, without increasing qualifications of teacher educators, it will be difficult for them to teach the technology contents in the curriculum. Proper in-service teacher education can decrease this knowledge gap up to a certain level, but still the effectiveness of the transaction done by reeducated teacher educators is par below the requirements of the curriculum. The recourse availability for techno pedagogy is another critical issue we have to deal with. There are around one fifty D.Ed. colleges in Kerala, out of which only a handful are having enough computers, projectors and other audio visual equipment. Availability of internet, is another important factor. Most of the colleges doesn't have their own website or even internet connection. So, it will be difficult for the teacher educators to perform most of the transaction items that require ICT. The paper that introducing ICT is part of the first semester. In Kerala, the D.Ed. admissions are delayed up to two three months. This will directly impact the quality of teaching and learning of the papers allotted to first semester. So, ICT education also impacted in this manner. Ensuring timely completion of D.Ed. admissions is complicated by many social and political reasons starting from availability of interested students to delayed decision making by concerned authorities. Motivating teacher educators and student teachers for using ICT in classrooms is another big challenge. Teacher educators in government and aided colleges are mostly promoted from secondary schools after completing ten to fifteen years in service. The have the tendency to train the ways they followed. The education authorities have a tendency to ignore $\mathrm{D}$. Ed. Teachers from the ongoing trainings. In unaided colleges, the situation is even worse. Only the head of the institution can help in this situation. But how much the head of the colleges are motivated in this matter is another unanswered question.

\section{SUGGESTIONS FOR THE BETTER INFUSION OF TECHNO} PEDAGOGICAL SKILLS FOR TEACHER EDUCATION

The review of the teacher education syllabus reveals that; the revised and restructured teacher education curriculum gives enough importance to technology integration. As far as improving techno pedagogical skills of teacher trainees are concerned, there are still many doubts will arise on the effective implementation. Some of the concerns are availability of technology infrastructure, skills needed for teacher educators to teach technology related elements, availability of time, motivation, quality of resources etc. Following are few of the suggestions to improve the techno pedagogical skill of prospective teachers, derived from the review of the syllabus.

$>$ Increase qualification of teacher educators and conduct more in-service teacher training courses on ICT

$>$ Make sure the availability of technology resources and Internet in each and every D.Ed. college.

$>$ Timely completion of admission process

$>$ Familiarize with the government's ICT framework and policy Documents, Understanding and participating in government initiatives like it@school.

$>$ Study of high quality sources - academic books on ICT and sources that give practical ideas about how to proceed

$>$ Motivation and initiation for ICT integration (usually comes from principals of the colleges)

$>$ Keep your ICT competency development goals simple and flexible. When setting your goals, think about the areas of learning and development

$>$ While selecting, resources check SCERT/Government regulations

$>$ Build ICT labs based on manageability, safety, practicality, and flexibility

$>$ ICT professional development is a continuous lifelong process of personal growth.

$>$ Estimate or evaluate the actual level of the ICT competency of your teachers and how much they are motivated to develop further 
Develop your personal strategy for planning, observing and evaluating the long-term process of the professional development of your staff.

$>$ Create and support the atmosphere of the learning community within your center, where people value expertise, where they learn from each other on daily basis, value expertise and support each other

\section{CONCLUSION}

Like all the other aspects of human life, education also significantly contributed by modern day technologies. Elementary school teachers have a new responsibility to use ICT in their day to day teaching life, to enrich the lives of children they teach. The present investigation revealed that, techno pedagogy has given outstanding weightage in the newly revised elementary teacher education syllabus. But to facilitate pre-service teachers to improve their techno pedagogical skills, the present teacher education scenario has to improve upon most of the impeding factors. Government, teacher educators, teacher training institutions and other accreditation or facilitating agencies should co-operate and realign their current efforts and improve upon them to mentor and facilitate teacher trainees to develop their techno pedagogical skills.

\section{REFERENCES}

[1] Archambault, L., \& Crippen, K. (2009). Examining TPACK among K-12 online distance educators in the United States. Contemporary Issues in Technology and Teacher Education, 9(1), 71-88. Retrieved from http://www.citejournal. org/vol9/iss1/general/article2.cfm

[2] Recognising the potential of ICT in early childhood education by UNESCO (http://iite.unesco.org/publications/3214673/

[3] Beaudin, L., \& Hadden, C. (2004). Developing techno pedagogical skills in preservice teachers. In Proceedings of World Conference on E-Learning in Corporate, Government, Healthcare, and Higher Education 2004, 492-498. Norfolk,VA: Association for the Advancement of Computing in Education. Retrieved from http://www.innovateonline.info/index.php?view=article\&id=36

[4] Koehler, M. J., \& Mishra, P. (2005). What Happens When Teachers Design Educational Technology? The Development of Technological Pedagogical Content Knowledge. Journal of Educational Computing Research, 32(2), 131-152.

[5] Monsivais, M. I., McAnally, L., \& Lavigne, G. (2014). Application and validation of a technopedagogical lecturer training model using a virtual learning environment. Revistade Universidady Sociedaddel Conocimiento, 11(1), 91-107. Retrieved from http://doi.dx.org/10.7238/rusc.v11i1.1743

[6] National Curriculum framework, New Delhi: National Council of Educational Research and Training, 2009http://ncte-india.org/ncte_new/pdf/NCFTE_2010.pdf

[7] Report of the working group on higher education for the xii-five-year plan, Government of India: Ministry of Human Resource Development, Department of Higher Education, 2011

[8] Sathiyaraj, K., \& Rajasekar, S. (2013). The Relationship between the Techno-Pedagogical Competency of Higher Secondary School Teachers and their Anxiety towards the Use of Instructional Aids in Teaching. International Journal of Teacher Educational Research, 2(12), 7-14. syllabus for (http://www.scert.kerala.gov.in/index.php?option=com_content\&view=article\&id=121\&Itemid=99)

[10] Yurdakul, K. (2011). Examining Techno Pedagogical Knowledge Competencies of Preservice Teachers Based on ICT Usage. Hacettepe Universitesi Egitim Fakultesi Dergisi Journal of Education, 40, 397-408. 